\title{
Pendekatan Reader Response Criticism terhadap Narasi Tulah di Mesir dalam Peristiwa Keluaran
}

\section{Sonny Eli Zaluchu}

Sekolah Tinggi Teologi Baptis Indonesia (STBI) Semarang, Indonesia; e-mail: gloryofgodmin@gmail.com

Received: 2020-08-03; Accepted: 2020-12-22; Published: 2020-12-31.

\begin{abstract}
Reader Response Criticism (RRC) is a postmodern hermeneutic approach that emphasizes meaning lies not in the hands of the writer or text but the reader's hands. With this method, the approach to obtaining meaning depends very much on the reader's experience and the extent to which he places himself in the text. The problem is when this approach used for hermeneutical scriptures, and some new meanings emerge that even outperform mainstream textual meanings. This paper contains a discussion of the RRC approach and its use in analyzing the scriptures. The narrative used is the portion of the exodus of the children of Israel from Egypt, where Elohim dropped ten plagues upon Egypt. New meaning instruments produced with this approach, such as plagues, are not merely miracle stories but products of natural phenomena. Likewise, the act of God in the plagues can be understood as an act of anger and discrimination. It can conclude that as a critical approach, the RRC method could not be entirely applied to hermeneutical scriptures because there are parts of the scriptures that must be preserved literally as part of the truth of the faith of believers. While on the other hand, the RRC is open to multiple meanings, which contradict the literal meaning in the text and context.
\end{abstract}

Keywords: bible criticism; hermeneutics; postmodern; reader response criticism; ten plagues.

Abstrak: Reader Response Criticism adalah pendekatan hermenetika postmodern yang menekankan makna terletak bukan di tangan penulis atau teks melainkan di tangan pembaca. Dengan metode ini, pendekatan untuk mendapatkan makna sangat bergantung dari pengalaman pembaca dan sejauh mana menempatkan dirinya di dalam teks. Persoalannya, ketika pendekatan ini dipergunakan untuk hermenetika kitab suci maka muncul sejumlah makna baru yang bahkan mengungguli makna tekstual mainstream. Paper ini berisi pembahasan tentang pendekatan RRC dan penggunaannya di dalam menganalisis kitab suci. Narasi yang dipergunakan adalah bagian eksodus bani Israel dari Mesir manaka Elohim menjatuhkan sepuluh tulah kepada Mesir. Instrumen makna baru dihasilkan dengan pendekatan ini seperti tulah bukan semata-mata kisah keajaiban tetapi produk dari fenomena alam. Demikian juga dengan tindakan Elohim di dalam tulah itu dapat dipahami sebagai sebuah tindakan kemarahan dan diskriminasi. Dapat disimpulkan bahwa sebagai sebuah pendekatan kritis, metode RRC tidak dapat seluruhnya diterapkan untuk hermenetika kitab suci karena terdapat bagian-bagian kitab suci yang harus dipertahakan makna literalnya sebagai bagian dari kebenaran iman orang percaya. Sementara di sisi lain, RRC terbuka untuk makna ganda yang justru bertentangan dengan makna literal di dalam teks dan konteks.

Kata Kunci: hermenetika; kritik Alkitab; kritik respon pembaca; paska modern; sepuluh tulah.

\section{Pendahuluan}

Tiga permasalahan di dalam penafsiran Alkitab adalah sebagai berikut. Pertama, terdapat kesenjangan waktu (distance of time) antara peristiwa Alkitab dengan pembaca modern (Klein, Blomberg, \& Hubbart, 2004, hal. 13). Sepuluh tulah yang terjadi di Mesir, merupakan peristiwa yang berkaitan dengan keluarnya bani Israel dari Mesir di bawah pimpinan Musa (Silva, 2018). Kejadian tersebut berlangsung sekitar tahun 1440 SM. Catatan di dalam kitab 1 Raja-raja 6:1 dapat dirujuk untuk menghitung tahun eksodus. Bangsa Israel keluar dari Mesir 480 tahun sebelum Salomo mendirikan 
Bait Allah pada tahun 966 SM. Perhitungan mundur dari pembangunan Bait Allah Salomo menghasilkan tahun 1446 SM (Nelson, 1993, hal. 23). Pembaca modern dituntut memahami peristiwa yang telah terjadi lebih dari seribu empat ratus tahun yang lalu. Tidak ada referensi manapun yang dapat dijadikan pegangan kecuali Alkitab.

Kedua, sepuluh tulah terjadi di Mesir, sebuah kerajaan di benua Afrika yang dipimpin oleh Firaun. Pada masa itu, Mesir merupakan kerajaan yang sangat maju di dalam segala hal seperti pengetahuan, hasil bumi , militer dan politik serta kebudayaan masyarakat yang sangat maju. Pengetahuan orang Mesir tentang mumifikasi hingga saat ini menjadi misteri, sama misterinya dengan upaya pembaca modern untuk mempelajari cara membangun piramid yang megah tersebut. Kesenjangan kebudayaan terjadi di dalam hal ini. Pada zaman eksodus teknologi tidak seperti abad 21 dimana semua serba digital dan otomatis. Pembentukan masyarakat dan kebudayaan sangat jauh berbeda. Pembaca modern dituntut kembali ke belakang di masa Firaun untuk memahami bagaimana situasi politik, ekonomi dan sosial budaya pada masa itu. Kesenjangan budaya (cultural distance) merupakan tantangan tersendiri di dalam hermenetika (Klein et al., 2004).

Yang lebih sulit adalah kesenjangan geografis (geographical distance). Dimana letaknya istana Firaun pada masa itu dan di mana Harun mencelupkan tongkatnya disungai Nil sehingga air berubah menjadi darah; atau apakah terdapat sisa-sisa hujan es, dan hujan api dari langit; bahkan situs Gosyen yang menjadi tempat tinggal bani Israel 430 tahun, menjadi pertanyaan yang jawabannya hanya dapat ditemukan oleh bukti arkeologi. Akan tetapi, kesenjangan ketiga ini tidak cukup memberi informasi untuk memahami peristiwa eksodus dan terjadinya sepuluh tulah. Tempat-tempat tersebut tidak dapat dipastikan secara akurat karena geografisnya sudah berubah (Klein et al., 2004). Waktu telah mengikis semua bukti sehingga pembaca modern tidak dapat melakukan verifikasi dan penelitian di laboratorium untuk menguji apakah betul-betul air sungai Nil berubah menjadi darah sungguhan. Demikian halnya dengan terjadinya kegelapan yang menutupi seluruh daratan Mesir, tidak dapat dibuktikan oleh ilmu pengetahuan modern apakah hal tersebut terjadi karena matahari "mati" selama tiga hari atau terdapat penjelasan lain yang lebih masuk akal.

Kesenjangan yang terjadi antara peristiwa aktual di dalam narasi eksodus dengan pembaca modern yang berusaha mempelajarinya menyisakan banyak pertanyaan yang berujung pada usaha untuk menafsirkan sedekat mungkin dengan peristiwa. Jika memilih pendekatan diakronik, maka penafsir modern harus mempelajari banyak hal dan menyusuri waktu secara kronologis untuk mengamati peristiwa yang terjadi. Analisis harus dimulai pada titik awal peristiwa di dalam rentang sejarah. Hal ini tidak mudah kecuali bagi peneliti dan ahli Perjanjian Lama yang pasti memiliki wawasan akademik dan latar belakang historis yang kuat. Maka pilihan bagi pembaca modern terlebih kaum awam adalah cara berpikir sinkronik. Seperti berada di depan cermin, pembaca melihat dan mengamati terjadinya sepuluh tulah dalam kacamata dan waktu saat ini. Pendekatan ini tidak menganalisis suatu peristiwa dari awal dan hanya melihatnya dari titik dimana pembaca berada dan mengamati teks tersebut. Pendekatan ini bertolak belakang dengan diakronik. Sinkronik menyempit hanya melihat peristiwa sepuluh tulah dan menganalisisnya di dalam pola dan gejala saja dengan analisis dan pendekatan yang tentu saja sesuai dengan kondisi pembacanya (Soulen \& Soulen, 2001, hal. 47).

Oleh sebab itu, di dalam penelitian ini, penulis hendak mengungkap cara pandang sinkronik peristiwa eksodus hanya pada satu titik yakni peristiwa sepuluh tulah. Penelitian sebelumnya tentang topik sinkronik ini pernah dilakukan oleh Nobel tetapi hanya fokus pada metodenya dan bukan pada aplikasi metode itu terhadap narasi-narasi Alkitab (Nobel, 1993). Penelitian yang lebih baru dari Talsir juga membahas dari aspek metodologi saja dan perbedaaannya dengan pendekatan diaktonik (Talshir, 2018). Untuk mendukung pembahasan, analisis sinkronik terhadap narasi tulah di dekati dengan kritik respons pembaca. Jenis kritik ini mendukung pola berpikir sinkronik untuk mengungkap bagaimana pembaca modern yang berpikir ilmiah, logis dan kritis, melihat dan mengamati sepuluh tulah sebagai unit analisis. Langkah-langkah yang dilakukan penulis adalah pertama, anatomi dari Reader Respons Criticism di dalam caranya menemukan makna teks dan peran pembaca di dalam penafsiran penemuan makna-makna baru. Langkah berikutnya adalah menjelaskan narasi sepuluh tulah di dalam Kitab 
Keluaran 7-12 menurut plot, pola dan strukturnya sehingga pembaca dapat memiliki wawasan terhadap makna tekstual teks. Bagian ketiga adalah menyusun alternatif makna dengan menggunakan pola pikir reader respons criticism terhadap teks di dalam sebuah rangkaian analisis. Tujuannya ada dua. Memaparkan bagaimana teknik ini digunakan untuk menafsirkan teks kitab suci dan kedua untuk menemukan hal-hal baru yang bertitik tolak pada kajian empiris-logis sebagai pertimbangan paralel terhadap penafsiran klasik mainstream.

\section{Anatomi Reader Respons Criticism dalam Pencarian Makna}

Hermenetika kita suci mengenal tiga kategori kritik. Yang pertama, kritik rendah. Jenis kritik ini berusaha mengangkat makna dari teks asli melalui naskah yang ada dengan eksegesis. Penafsir berusaha untuk masuk ke dalam alam berpikir penulis, mengenali konteks narasi yang melingkupi teks dan mendalami makna dengan meneliti makna bahasa dari teks.

Kelompok kedua adalah tafsir modern. Pendekatannya sangat bertolak belakang dan berbeda dari yang pertama sehingga disebut sebagai kritik tinggi (tetapi tidak berarti lebih tinggi secara harafiah). Unsur-unsur seperti jenis kategori sastra, penelitian sumber teks dan asal usulnya, aspek historis, sistem tradisi, redaksi dan tata bahasa serta jenis narasi ikut diperhitungkan di dalam usaha mengangkat makna. Pendekatan yang dilakukannnya menempatkan teks kitab suci sebagai karya sastra belaka dan terbuka untuk dilihat dengan berbagai pendekatan filsafat, wacana, prinsip-prinsip sosial-politik-kebudayaan, logika dan pendekatan akademik lainnya. Fokusnya adalah transformasi dan perubahan teks (sejarah teks) dan sejarah di dalam teks, sehingga muncul istilah baru dari pendekatan ini dengan nama kritik historis. Makna adalah kombinasi dari keduanya. Sebagai catatan, kedua kritik tersebut di atas, dinamakan 'rendah' dan 'tinggi', tidak merujuk pada 'posisi' atau kualitas yang diartikan secara harafiah. Istilah rendah (low criticism) dan tinggi (high criticism) hanya sekedar kontras di antara kedua teknik hermenetika teologi Kristen yang saling bertolak belakang dan berbeda pendekatannya (Soulen \& Soulen, 2001).

Memasuki abad ke-20 muncul pemikiran postmodern dengan tokoh-tokoh seperti Derida, Foucault, Lyotard, dll. Pendekatan baru terhadap hermenetika kitab suci bergeser kepada prinsip baru. Kitab suci ditafsir dengan template postmodern. Tidak seperti kritik rendah dan kritik tinggi yang masih setia pada penulis dan teks, pendekatan postmodern justu mengabaikan penulis dan teks dan lebih fokus pada makna menurut pembaca modern. Salah satu pendekatan postmodern itu adalah kritik respon pembaca atau Reader Response Criticism atau disingkat RRC (Zaluchu, 2020a). Jika strukturalisme membahas bagaimana teks mengkomunikasikan makna dan post-strukturalisme membahas alasan dibalik komunikasi makna oleh teks, maka RRC melampauhi keduanya dengan mencari makna kekinian menurut pembaca modern (Grimaud \& Tompkins, 1982).

Pendekatan ini setuju bahwa setiap teks membawa makna dan pembaca berperan di dalam menemukan makna tersebut (Mantiri, 2019). Dengan demikian makna sebuah teks sangat bergantung pada penafsiran pembacanya dan tidak bisa dibatasi oleh metode. Sebab menurut Sumaryono, hermenetika pada dasarnya memiliki prinsip open-mindedness (Sumaryono, 2018, hal. 142). Dengan kata lain, pendekatan RRC menggeser pendekatan dari text-based kepada reader-based. Pembaca adalah penentu makna. Penulis hanya dianggap sebagai bagian natural yang melahirkan teks dan pembaca secara otonom bebas menentukan maknanya (Grimaud \& Tompkins, 1982; Schmitz, 2008). Dengan pola kerja yang seperti ini, maka makna sangat bergantung pada situasi lingkungan, presuposisi dan rasionalitas pembaca. Osborne mengatakan bahwa makna merupakan perpaduan antara teks dan pembaca pada momen respons (Osborne, 2006, hal. 565-571). Faktor latar belakang dan kecenderungan pribadi pembaca sangat mempengaruhi proses pencarian makna sehingga pembaca terlihat sebagai pencipta daripada penulis yang menghasilkan teks. Hasilnya sebuah teks dapat saja menghasilkan makna-makna baru yang mungkin bisa bergeser dari maksud pertama penulisnya (Osborne, 2012, hal. 583). Sehingga karena bergantung pada respon pembaca, unsur subjektifitas di dalam pemaknaan sangat besar.

Cara kerja RRC dapat dilihat dari dua kelompok besar di dalam pendekatan ini. Pertama diusulkan oleh Iser melalui konsep determinasi-determinasi. Menurutnya, setiap teks memiliki celah 
yang menjadi pintu masuk bagi pembaca untuk terlibat di dalamnya. Dialektika dari detereminasi di dalam teks dan perspektif yang dibawa oleh pembaca saat memasuki teks melahirkan makna. Dalam hal ini pembaca modern menempatkan diri bersama-sama dengan pembaca tersirat untuk melengkapi makna tekstualnya. Pola kerjanya adalah, setelah membaca teks, pembaca mencari celah determinasi dan masuk ke dalam dunia narasi untuk mengikuti urutan internal, plot, narasi yang disebutnya sebagai repertorium sehingga pembaca dipaksa untuk melengkapi makna teks tersebut (O'Hara \& Iser, 1979, hal. 24-25; Osborne, 2012). Iser terlihat masih setia dan berpusat pada teks dengan mengutamakan strateginya sebagai salah satu komponen makna.

Usulan kedua datang dari dari Stanley Fish yang menekankan strategi membaca sebagai komponen satu-satunya. Bagaimana pembaca modern 'membaca' suatu teks akan sangat menentukan makna yang diperoleh dari teks. Dalam pola ini, teks memasok pembaca dengan sejumlah kemungkinan makna yang kemudian diaktualisasi oleh pembaca dengan cara memilih makna yang sesuai dengan strategi penafsirannya sendiri. Dengan kata lain, aktulisasi mengijinkan adanya variasi makna karena pengalaman pembaca dengan teks dapat berbeda setiap kali membacanya (Fish, 1980, hal. 11-14; Osborne, 2012).

\section{Struktur dan Pola Sepuluh Tulah di Mesir}

Situasi yang melatarbelakangi terjadinya sepuluh tulah di Mesir adalah keinginan Elohim untuk mengakhiri perbudakan bani Israel di Mesir oleh Firaun. Menurut catatan, ada dua teori tentang Firaun yang berkuasa pada masa itu. Merujuk 'early date theory' terdapat nama Amenhotep II (1450-1425 SM). Tetapi berdasarkan 'late theory' muncul nama Rameses II (1304-1236) (Nelson, 1993). Kemungkinan besar itu Rameses II karena dari dua kota yang dibangun bani Ibrani salah satunya menggunakan nama Raamses. Firaun kuatir dengan pertambahan jumlah bani Israel di Mesir dapat berubah menjadi ancaman domestik sehingga dengan keras menjadikan kelompok pendatang ini sebagai budak untuk membangun kota.

Doa dan seruan serta penderitaan bani Israel menjadi prioritas Elohim sehingga mengutus Musa kepada Firaun untuk melepaskan bangsa ini dari perbudakan dan mengijinkan mereka keluar dari Mesir. Tetapi Firaun mengeraskan hati dan bergeming. Negosiasi gagal dan sepanjang negosiasi itu, Elohim menjatuhkan hukuman untuk menekan Firaun. Alkitab mencatat di dalam Kitab Keluaran 712 terdapat sepuluh hukuman yang dijatuhkan pada Firaun dan melanda seluruh daratan Mesir. Hukuman itu disebut sepuluh tulah (the ten plagues) di dalam kitab suci Kristiani.

Tabel 1 menampilan daftar sepuluh tulah yang melanda Mesir berdasarkan struktur, sistematika dan plot disertai catatan analisis. Sepuluh tulah tersebut menurut Wenham memperlihatkan keperkasaan Elohim atas Mesir dan dewa-dewanya yang memberi informasi bahwa Dia adalah pencipta yang sejati yang mampu mengontrol dan mengendalikan alam dan semua hal, sekaligus memperlihatkan ketidakberdayaan Firaun (Wenham, 2003, hal. 62). Pada masa itu, kerajaan Mesir sangat maju di dalam peradaban dan kekuasaan politik-militer. Melalui tulah, berlangsung serangan kepada semua dewa Mesir dan segala bentuk kekuasaan mereka yang selama ini dipercaya orang Mesir. Terjadi perang yuridiksi dibawah kendali Elohim. Dari seharusnya melindungi orang-orang Mesir justru berbalik menyerang mereka sendiri. Katak, buaya, banteng, sapi yang menjadi representatif dewa dan sejumlah sesembahan penguasa langit dan udara tidak berdaya dan dikendalikan oleh Elohim (Blumenthal, 2012). Bahkan matahari sebagai salah satu dewa tertinggi dibuat gelap selama tiga hari-tiga malam.

Terlihat bahwa narasi tentang tulah memperihatkan pola sistematis, progresif dan meningkat kualitasnya. Puncaknya adalah kematian. Alasan teologis dibalik kejadian tersebut untuk memperlihatkan bahwa pusat kehidupan sejati adalah Elohim sendiri. Meskipun alasan ini terkesan normatif secara teologis, melalui hal ini muncul deklarasi tentang hegemoni Elohim terhadap dua sisi: untuk mendidik Firaun dan seluruh Mesir dan untuk menegaskan eksistensiNya di tengah bani Israel (Zaluchu, 2020b, hal. 142). Klasifikasi kepentingan wabah yang dibuat oleh Grossman sangat penting. Tujuh wabah pertama, berakhir dengan wabah hujan es, dirancang untuk mendidik Firaun dan orang- 
orang Mesir, sementara tiga wabah terakhir juga diarahkan untuk pendidikan orang Israel sendiri (Grossman, 2014).

Tabel 1 Daftar sepuluh tulah yang melanda Mesir

\begin{tabular}{|c|c|c|c|}
\hline Tulah & Teks & Analisis & Aktor \\
\hline $\begin{array}{l}\text { Tulah pertama } \\
\text { Air berubah menjadi } \\
\text { darah } \\
(7: 19-21)\end{array}$ & $\begin{array}{l}\text { Demikianlah Musa dan Harun } \\
\text { berbuat seperti yang } \\
\text { difirmankan TUHAN; } \\
\text { diangkatnya tongkat itu dan } \\
\text { dipukulkannya kepada air yang } \\
\text { di sungai Nil, di depan mata } \\
\text { Firaun dan pegawai- } \\
\text { pegawainya, maka seluruh air } \\
\text { yang di sungai Nil berubah } \\
\text { menjadi darah; matilah ikan di } \\
\text { sungai Nil, sehingga sungai Nil } \\
\text { itu berbau busuk dan orang } \\
\text { Mesir tidak dapat meminum air } \\
\text { dari sungai Nil; dan di seluruh } \\
\text { tanah Mesir ada darah. }\end{array}$ & $\begin{array}{l}\text { Air merupakan kebutuhan bagi orang } \\
\text { Mesir. } 80 \% \text { wilayahnya adalah padang } \\
\text { pasir. Kota-kota dan pemukiman } \\
\text { dibangun disepanjang tepi sungai Nil } \\
\text { sebagai satu-satunya sumber air yang } \\
\text { menunjang kehidupan dan pertanian. } \\
\text { Tuhan mengubah air sungai itu menjadi } \\
\text { darah. Sungai Nil adalah habitat dari } \\
\text { buaya Afrika yang juga menjadi salah } \\
\text { satu dewa bernama 'sobek'.Juga } \\
\text { terdapat dewa 'sothis' yang menjadi } \\
\text { penguasa sungai Nil. Demikian juga } \\
\text { dengan dewa Hapi yang gemuk, } \\
\text { menjadi dewa genangan sungai Nil. } \\
\text { Akibat tulah, kehidupan terancam. Ikan- } \\
\text { ikan mati dan bau busuk mengotori } \\
\text { udara. Orang Mesir tidak dapat minum } \\
\text { dan menyiram tanaman. }\end{array}$ & $\begin{array}{l}\text { Elohim bertindak } \\
\text { melalui Harun }\end{array}$ \\
\hline $\begin{array}{l}\text { Tulah kedua } \\
\text { Katak memenuhi } \\
\text { seluruh Mesir } \\
(8: 5-6)\end{array}$ & $\begin{array}{l}\text { Berfirmanlah TUHAN kepada } \\
\text { Musa: "Katakanlah kepada } \\
\text { Harun: Ulurkanlah tanganmu } \\
\text { dengan tongkatmu ke atas } \\
\text { sungai, ke atas selokan dan ke } \\
\text { atas kolam, dan buatlah katak- } \\
\text { katak bermunculan meliputi } \\
\text { tanah Mesir." Lalu Harun } \\
\text { mengulurkan tangannya ke atas } \\
\text { segala air di Mesir, maka } \\
\text { bermunculanlah katak-katak, } \\
\text { lalu menutupi tanah Mesir. }\end{array}$ & $\begin{array}{l}\text { Heket adalah dewi Mesir berwujud } \\
\text { katak. Elohim menggunakan dewi } \\
\text { mereka menyerang Mesir. Aktifitas dan } \\
\text { pekerjaan dan kehidupan terganggu } \\
\text { oleh katak-katak tersebut. Tetapi Firaun } \\
\text { tetap mengeraskan hatinya apalagi } \\
\text { setelah ahli-ahli sihirnya mampu } \\
\text { melakukan hal yang sama. }\end{array}$ & $\begin{array}{l}\text { Elohim bertindak } \\
\text { melalui Harun }\end{array}$ \\
\hline $\begin{array}{l}\text { Tulah ketiga } \\
\text { Nyamuk dari debu } \\
\text { tanah } \\
(8: 16-17)\end{array}$ & $\begin{array}{l}\text { Berfirmanlah TUHAN kepada } \\
\text { Musa: "Katakanlah kepada } \\
\text { Harun: Ulurkanlah tongkatmu } \\
\text { dan pukulkanlah itu ke debu } \\
\text { tanah, maka debu itu akan } \\
\text { menjadi nyamuk di seluruh } \\
\text { tanah Mesir." Lalu mereka } \\
\text { berbuat demikian; Harun } \\
\text { mengulurkan tangannya dengan } \\
\text { tongkatnya dan } \\
\text { memukulkannya ke debu tanah, } \\
\text { maka nyamuk-nyamuk itu } \\
\text { hinggap pada manusia dan pada } \\
\text { binatang. Segala debu tanah } \\
\text { menjadi nyamuk di seluruh } \\
\text { tanah Mesir. }\end{array}$ & $\begin{array}{l}\text { Mesir adalah negara gurun. Pasir dan } \\
\text { debu sangat banyak. Tuhan } \\
\text { menjatuhkan tulah ketiga kepada Firaun } \\
\text { dengan mengubah debu menjadi lalat } \\
\text { dan hinggap pada semua rumah, istana, } \\
\text { makanan orang Mesir. Hal itu } \\
\text { menjiiikkan karena lalat dapat menjadi } \\
\text { pembawa virus dan bakteri. Para ahli } \\
\text { sihir Mesir kali ini tidak bisa menirunya } \\
\text { dan berkata kepada Firaun, "inilah } \\
\text { tangan Allah" Firaun tetap bergeming. }\end{array}$ & $\begin{array}{l}\text { Elohim bertindak } \\
\text { melalui Harun }\end{array}$ \\
\hline $\begin{array}{l}\text { Tulah keempat } \\
\text { Lalat pikat } \\
(8: 24)\end{array}$ & $\begin{array}{l}\text { TUHAN berbuat demikian; } \\
\text { maka datanglah banyak-banyak } \\
\text { pikat ke dalam istana Firaun dan } \\
\text { ke dalam rumah pegawai- } \\
\text { pegawainya dan ke seluruh } \\
\text { tanah Mesir; negeri itu } \\
\text { menderita karena pikat itu. }\end{array}$ & $\begin{array}{l}\text { Lalat pikat adalah lalat berukuran besar } \\
\text { yang senang menjilat dan menghisap } \\
\text { darah manusia. Hidup bergerombol. } \\
\text { Seluruh Mesir dipenuhi lalat ini dan } \\
\text { menyerang ternak serta manusia. Firaun } \\
\text { melunak dengan mengijinkan umat } \\
\text { Israel pergi. Tetapi sesaat setelah Musa } \\
\text { berdoa dan lalat-lalat ini pergi, Firaun } \\
\text { kembali kepada sifat aslinya, } \\
\text { mengeraskan hati dan melarang orang } \\
\text { Israel meninggalkan Mesir. }\end{array}$ & $\begin{array}{l}\text { Elohim sendiri } \\
\text { yang bertindak }\end{array}$ \\
\hline
\end{tabular}




\begin{tabular}{|c|c|c|c|}
\hline Tulah & Teks & Analisis & Aktor \\
\hline $\begin{array}{l}\text { Tulah kelima } \\
\text { Segala ternak di Mesir } \\
\text { mati } \\
(9: 6)\end{array}$ & $\begin{array}{l}\text { Dan TUHAN melakukan hal itu } \\
\text { keesokan harinya; segala ternak } \\
\text { orang Mesir itu mati, tetapi dari } \\
\text { ternak orang Israel tidak ada } \\
\text { seekorpun yang mati. }\end{array}$ & $\begin{array}{l}\text { Disini Elohim membuat perbedaan. } \\
\text { Segala ternak milik orang Mesir mati } \\
\text { tetapi milik orang Israel tetap hidup. } \\
\text { Dalam sistem keagamaan Mesir, } \\
\text { beberapa dewa yang dipersonifikasikan } \\
\text { dan ditampilkan dengan wajah } \\
\text { binatang, antara lain: banteng (dewa } \\
\text { apis), sapi (dewa hathor). Ternyata } \\
\text { binatang yang dianggap dewa tidak } \\
\text { berdaya dan mati oleh kuasa Elohim. }\end{array}$ & $\begin{array}{l}\text { Elohim sendiri } \\
\text { yang bertindak }\end{array}$ \\
\hline $\begin{array}{l}\text { Tulah keenam } \\
\text { Barah } \\
(9: 10)\end{array}$ & $\begin{array}{l}\text { Lalu mereka mengambil jelaga } \\
\text { dari dapur peleburan, dan } \\
\text { berdiri di depan Firaun, } \\
\text { kemudian Musa } \\
\text { menghamburkannya ke udara, } \\
\text { maka terjadilah barah, yang } \\
\text { memecah sebagai gelembung } \\
\text { pada manusia dan binatang, } \\
\end{array}$ & $\begin{array}{l}\text { Barah adalah sejenis penyakit kulit yang } \\
\text { ganas dan menyakitkan. Seluruh Mesir } \\
\text { terkena tulah ini termasuk pada ahli-ahli } \\
\text { sihir. Kulit mereka bengkat dan } \\
\text { bernanah. Penyakit ini tergolong kanker } \\
\text { kulit yang ganas. }\end{array}$ & $\begin{array}{l}\text { Elohim bertindak } \\
\text { melalui Musa }\end{array}$ \\
\hline $\begin{array}{l}\text { Tulah ketujuh } \\
\text { Hujan es, guruh dan } \\
\text { api dari langit } \\
(7: 23)\end{array}$ & $\begin{array}{l}\text { Lalu Musa mengulurkan } \\
\text { tongkatnya ke langit, maka } \\
\text { TUHAN mengadakan guruh } \\
\text { dan hujan es, dan apipun } \\
\text { menyambar ke bumi, dan } \\
\text { TUHAN menurunkan hujan es } \\
\text { meliputi tanah Mesir. }\end{array}$ & $\begin{array}{l}\text { Ketidakberdayaan dewa Mesir kembali } \\
\text { diperlihatkan disini. Dewa langit 'shu', } \\
\text { penuasa udara dewa 'nut' serta 'horus' } \\
\text { sang penguasa langit tidak mampu } \\
\text { mengontrol cuaca. Hujan es disertai } \\
\text { guruh dan hujan api turun } \\
\text { menghancurkan rumah, bangunan, } \\
\text { menimpa manusia dan ternak di seluruh } \\
\text { daratan Mesir. }\end{array}$ & $\begin{array}{l}\text { Elohim bertindak } \\
\text { melalui Musa }\end{array}$ \\
\hline $\begin{array}{l}\text { Tulah kedelapan } \\
\text { Belalang } \\
(10: 13)\end{array}$ & $\begin{array}{l}\text { Lalu Musa mengulurkan } \\
\text { tongkatnya ke atas tanah Mesir, } \\
\text { dan TUHAN mendatangkan } \\
\text { angin timur melintasi negeri itu, } \\
\text { sehari-harian dan semalam- } \\
\text { malaman, dan setelah hari pagi, } \\
\text { angin timur membawa belalang. }\end{array}$ & $\begin{array}{l}\text { Belalang memenuhi seluruh Mesir. } \\
\text { Mereka melahap semua tanaman hijau } \\
\text { dan tumbuhan hingga ke akarnya. } \\
\text { Memenuhi setiap tempat dan } \\
\text { menggunduli tanah Mesir. }\end{array}$ & $\begin{array}{l}\text { Elohim bertindak } \\
\text { melalui Musa }\end{array}$ \\
\hline $\begin{array}{l}\text { Tulah kesembilan } \\
\text { Kegelapan meliputi } \\
\text { seluruh Mesir } \\
(10: 22)\end{array}$ & $\begin{array}{l}\text { Lalu Musa mengulurkan } \\
\text { tangannya ke langit dan } \\
\text { datanglah gelap gulita di } \\
\text { seluruh tanah Mesir selama tiga } \\
\text { hari. }\end{array}$ & $\begin{array}{l}\text { Mesir menyembah dewa 'ra' yakni } \\
\text { matahari dan dewa 'khons' yakni bulan. } \\
\text { Khususnya dewa ra dianggap sebagai } \\
\text { dewa tertinggi dan melahirkan para } \\
\text { Firaun. Tetapi Elohim memperlihatkan } \\
\text { kuasaNya dengan menghadirkan } \\
\text { kegelapan tiga hari lamanya, }\end{array}$ & $\begin{array}{l}\text { Elohim bertindak } \\
\text { melalui Musa }\end{array}$ \\
\hline $\begin{array}{l}\text { Tulah kesepuluh } \\
\text { Semua anak sulung, } \\
\text { manusia dan binatang } \\
\text { mati } \\
(12: 29)\end{array}$ & $\begin{array}{l}\text { Maka pada tengah malam } \\
\text { TUHAN membunuh tiap-tiap } \\
\text { anak sulung di tanah Mesir, dari } \\
\text { anak sulung Firaun yang duduk } \\
\text { di takhtanya sampai kepada } \\
\text { anak sulung orang tawanan, } \\
\text { yang ada dalam liang tutupan, } \\
\text { beserta segala anak sulung } \\
\text { hewan. }\end{array}$ & $\begin{array}{l}\text { Ini merupakan tulah puncak. Segala } \\
\text { yang sulung di Mesir menjadi kudus } \\
\text { dan sangat berharga. Tetapi Tuhan } \\
\text { mengambil kehidupan tersebut untuk } \\
\text { membuktikan bahwa kehidupan itu } \\
\text { bukan milik para dewa melainkan } \\
\text { milikNya. Semua yang sulung, binatang } \\
\text { dan manusia, mati. Seluruh daratan } \\
\text { Mesir dipenuh ratapan kematian, } \\
\text { termasuk anak sulung Firaun sendiri. } \\
\text { Tetapi orang-orang Israel terlindungi. } \\
\text { Kali ini Firaun menyerah, "'Bangunlah, } \\
\text { keluarlah dari tengah-tengah bangsaku, } \\
\text { baik kamu maupun orang Israel; } \\
\text { pergilah, beribadahlah kepada TUHAN, } \\
\text { seperti katamu itu. Bawalah juga } \\
\text { kambing dombamu dan lembu sapimu, } \\
\text { seperti katamu itu, tetapi pergilah! Dan } \\
\text { pohonkanlah juga berkat bagiku" (12:31- } \\
\text { 32). }\end{array}$ & $\begin{array}{l}\text { Elohim sendiri } \\
\text { yang bertindak }\end{array}$ \\
\hline
\end{tabular}




\section{Analisis Reader Respons Criticism}

Pendekatan Reader Respon Criticism terhadap narasi sepuluh tulah dapat menghasilkan tafsiran yang berbeda-beda. Melalui tulisan ini penulis melihatnya di dalam dua aspek yakni peristiwa tulah itu sendiri dan alasan dibalik tindakan Elohim menjatuhkan tulah.

\section{Keajaiban atau kejadian alami}

Persoalan tentang sejumlah 'keajaiban' yang menyertai narasi sepuluh tulah di Mesir terus menjadi pergumulan para teolog sepanjang masa. Kelompok pertama adalah teolog yang memegang prinsip hermenetikaa tradisi bahwa ketika Harun memukulkan tongkatnya ke sungai Nil, betul-betul terjadi perubahan sifat air dari $\mathrm{H}_{2} \mathrm{O}$ menjadi cairan darah. Persoalan muncul di dalam narasi ini dan beberapa narasi lain. Ada kasus-kasus dimana para ahli sihir Firaun teryata mampu melakukan hal serupa. Tongkat para ahli sihir itu juga dapat melakukan keajaiban seperti tongkat mereka yang berubah menjadi ular, air berubah menjadi darah (tulah pertama), dan memunculkan katak seperti yang Harun lakukan (tulah kedua). Hal ini dapat menimbulkan pemaknaan baru bahwa tulah pertama dan kedua bukanlah sebuah peristiwa keajaiban dari Elohim. Situasi ini ikut memberi sumbangan di dalam hati Firaun untuk mempertahankan kekerasan hatinya. Tetapi di sisi lain, Elohim terlihat membawa narasi tulah ke dalam level baru dimana para ahli sihir Mesir gagal dan tidak mampu menirunya. Mulai dari tulah ketiga sampai tulah kesepuluh intensitas itu terlihat. Bahkan di dalam sejumlah tulah tersebut para ahli sihir Mesir dan Firaun sendiri ikut menjadi korbannya.

Makna baru yang mempertanyakan keajaiban juga terlihat pada tulah pertama hingga kesembilan. Para teologi modern percaya bahwa Musa dan Harun berada pada saat yang tepat di dalam siklus peralihan cuaca dan iklim Mesir. Pada waktu-waktu tertentu sebagaimana ditegaskan juga oleh Walton dkk bahwa beberapa tulah ini merupakan rangkaian dari sebuah siklus biologis yang saling terkait dalam hubungan sebab akibat (Walton, Matthews, \& Chavalas, 2000, hal. 83-84). Tulah kelima misalnya, berkaitan secara sistematis dengan keempat tulah sebelumnya. Kematian ternak disebabkan oleh antrax dari bakteri dan virus yang mengalir di sungai Nil dan pembusukan ikan-ikan, kemudian dibawa oleh katak dan lalat dan menularkannya pada ternak. Infeksi ini berada di dalam satu mata rantai kejadian (Walton et al., 2000).

Anaisis klasik Greta Hort juga dapat dipertimbangkan. Hort (1958, pp. 48-59) mengakui bahwa jika tulah dipandang sebagai sebuah keterlibatan aktif Elohim, hal tersebut tetap dapat dibenarkan. Akan tetapi, Hort juga menyodorkan makna baru tentang pentingnya mempertimbangkan fakta bencana rutin di dalam siklus cuaca dan iklim Mesir. Hadirnya gangguan dan bencana yang membuat penduduknya menderita seperti hujan es, badai pasir, dan kehadiran belalang misalnya, selalu terulang di dalam iklim Mesir. Hort melihat bahwa pada waktu peristiwa tulah terjadi, secara kronologis Mesir berada di dalam masa enam bulan bencana yang dipicu oleh kondisi cuaca yang aneh. Menurut argumentasinya, hujan deras di daerah tangkapan air sungai Nil menyebabkan banjir tahunan pada setiap bulan September. Tulah pertama melibatkan air yang berubah menjadi darah dan kematian ikan-ikan di sungai. Menurut Hort sebagaimana dikutip oleh Wenham (2003, p. 63), hal ini disebabkan oleh sejenis jamur atau bakteri berwarna merah dalam jumlah besar dari ujung Afrika dan mengalir ke hilir melalui wilayah Mesir sehingga mengubah air sungai terlihat merah darah. Bakteri dan jamur tersebut beracun dan membunuh ikan-ikan. Pembusukan semakin menambah kandungan mikroorganisme yang berbahaya di dalam sungai Nil (termasuk virus antrax yang sangat berbahaya itu). Berlanjut dengan perpindahan katak dari sungai menuju daratan. Kondisi lembab menyebabkan nyamuk dan lalat pikat berkembang biak dengan subur. Pada saat katak-katak tersebut mati, virus antrax yang dibawanya melekat pada kaki lalat sehingga menginfeksi ternak dan tubuh manusia. Hewan mati dan manusia terjangkit penyakit kulit yang berbahaya. Demikian juga dengan ketiga tulah berikutnya, hujan es, belalang, dan kegelapan. Kemungkinan besar ini adalah rangkaian anomali cuaca dan berkaitan dengan badai pasir di gurun. Jika penasihat kerajaan Mesir mengenali pola alami tersebut, akan lebih mudah memahami mengapa Firaun tetap bergeming dan mengabaikan tindakan 
Musa dan Harun. Firaun percaya setelah siklus ini berakhir keadaan akan pulih kembali seperti sedia kala di tahun depan.

Tetapi ketika wabah terakhir yang belum pernah terjadi sebelumnya melanda Mesir dapat terbaca di dalam narasi bahwa Firaun dan penasehatnya seolah sepakat kejadian ini sudah berada di dalam level yang tidak dapat diprediksi seperti kejadian yang berkaitan dengan alam dan iklim. Seluruh anak sulung baik ternak dan manusia, mati serentak di daratan Mesir. Dewa dewa Mesir tidak berdaya menghadirkan proteksi dari kematian. Kejadian ini menggetarkan hati Firaun sehingga merelakan bangsa Israel pergi meninggalkan Mesir.

Dalam perspektif ini terlihat bahwa tidak seluruhnya peristiwa tulah merupakan keajaiban karena fenomena tersebut dapat dijelaskan sebagai bagian dari praktik sihir ahli Mesir dan kejadian alam.

\section{Kekejaman dan Diskriminasi Elohim}

Diskriminasi rasial juga terlihat pada narasi. Sebagaimana politik diskriminasi yang pernah dijalankan di Afrika Selatan (Budiman, 2013), di dalam kisah Eksodus, terlihat adanya pembedaan perlakuan dan tindakan Elohim kepada Firaun dan orang Mesir dengan bani Israel. Unsur diskriminasi yang mengacu para ras terpenuhi (Armiwulan, 2015).

Pembaca modern dapat dengan cepat menangkap bahwa ada dua hal menonjol di dalam narasi tulah yakni sikap kejam Elohim terhadap Firaun dan penduduk Mesir dan proteksi serta perlindungan terhadap bani Israel. Sikap kejam tersebut terihat dari kedudukan Firaun dan penduduk Mesir sebagai objek kemarahan Elohim. Hal ini sebetulnya dapat dimengerti di dalam konteks narasi yang lebih luas bahwa semua itu merupakan tindakan hukuman terhadap Firaun dan penduduk Mesir yang telah berlaku semena-mena (memperbudak) bani Israel. Dalam hal ini ada dua makna yang bisa muncul jika pembaca menempatkan dirinya di dalam teks. Menjadikan Mesir sebagai objek kemarahan Elohim atau juga melihat penderitaan bani Israel sebagai budak selama ratusa tahun. RRC memberikan kesempatan yang luas di dalam membangun makna terhadap determinasi tersebut. Harus dipahami bahwa murka Elohim selalu tertuju pada segala hal yang melawan perintah dan kehendakNya. Dalam hal ini Firaun menempatkan dirinya dan seluruh Mesir dengan sengaja berada di dalam posisi berlawanan. Teologi Kristen tidak memberi ruang bagi citra Elohim yang ganas, kejam dan tidak berperikemanusiaan. Karena di sisi lain, bagi setiap orang yang mengikuti aturanNya dan atau bertobat, Elohim memiliki kekuatan untuk mengasihi dan mengampuni. Dalam hal ini manusialah yang menentukan reaksi Elohim atas perbuatan dan perilakunya. Itulah sebabnya Pawson dengan tegas menyatakan bahwa tulah Mesir berkaitan erat dengan pembalasan karena Mesir dianggap layak menerima hal tersebut akibat perlawanan mereka terhadap perintah Elohim (Pawson, 2015, hal. 120).

Hal kedua yang menonjol adalah diskriminasi. Bahkan ini sudah terlihat sejak Yakub dan anakananya hijrah ke Mesir. Keluarga besar ini dengan sengaja ditempatkan di tanah Gosyen yang terpisah dari daratan Mesir. Alasannya budaya menjadi penyebabnya. Yakub dan anak-anaknya hidup di kemah dan menjadi penggembala ternak. Profesi dan gaya hidup ini tidak sejalan dengan kebudayaan Mesir yang maju. Pembaca modern pasti dengan mudah mengenal bahwa unsur diskriminasi terlihat disini. Sejak awal tidak ada pembauran yang berlangsung antara orang Mesir dan bani Israel.

Fakta diskriminasi yang kedua terlihat dalam kejadian tulah yang hanya mengenai orang Mesir sementara bani Israel aman-aman saja. Bahkan pada tulah puncak, semua yang sulung dari Israel, baik ternak maupun anak sulung, tetap hidup karena proteksi Elohim. Seperti apapun makna teologis menjadi bobot di dalam tafsiran tradisional, dengan menggunakan RRC terlihat bahwa diskriminasi tetap menjadi tema sentral. Apakah Elohim dikatakan bertindak rasis dalam hal ini, sangat bergantung dari sejauh mana pembaca menempatkan dirinya di dalam teks. Nuansa diskriminasi ini semakin terlihat dengan tindakan Firaun yang memaksa orang-orang Israel untuk membuat batu bata. Tugas itu hanya dibebankan kepada orang Israel dan tidak melibatkan orang Mesir. Membuat batu bata di zaman itu adalah gambaran dari penindasan (Shanks, Dever, Halpern, \& Kyle McCarter, 2012).

Poin yang terlihat dari analisis ini adalah pembaca modern dapat secara kritis melihat Elohim dan tindakanNya. Dia dapat saja dipandang sebagai Tuhan yang kejam atau yang penuh perlindungan. Dapat dilihat sebagai Tuhan yang bertindak ataupun yang menghukum. Sentralitas penafsiran, 
sebagaimana dijelaskan sebelumnya terletak di tangan pembaca dan sejauh mana pembaca menempatkan narasi di dalam pengalamannya. Kemungkinan-kemungkinan mengenai makna teks adalah sesuatu yang dapat dibenaran melalui metode tafsir RRC.

\section{Kesimpulan}

Metode RRC merupakan salah satu pendekatan yang dapat dipakai untuk mencari makna teks di dalam narasi yang bergantung kepada pembaca dan responnya saat itu (realtime). Harus dipahami bahwa sebagai bagian dari kritis postmodern, kritik ini tidak sepenuhnya menerima teks kitab suci sebagai sesuatu yang inerrant dan abai terhadap otonomi kebenaran yang diungkap oleh teks itu sendiri. Oleh karena itu, RRC harus dipergunakan secara berhati-hati khususnya di dalam hermenetika kitab suci yang pada satu sisi memiliki kebenaran normatif dan absolut secara harafiah, dimana pembaca modern justru dituntut untuk menaklukan akal budinya ke dalam pengertian teks. Bukan justru mencari tandingan makna.

Tujuan dari kritik ini sebetulnya tidak jauh berbeda dengan usaha hermenetika, yakni untuk menemukan makna. Yang membedakannya adalah, kalau hermenetika mencari makna asli sebagaimana dimaksud penulis dan penerima teks di masa lalu, RRC memiliki pendekatan yang berbeda. RRC membangun makna secara subjektif dan sangat bergantung pada perspektif, presuposisi atau situasi yang dimiliki pembaca masa kini. Terbukti bahwa di dalam menafsirkan narasi tulah di Mesir, pendekatan RRC mampu merombak pemahaman tradisi tentang kejadian tersebut dan hadir dengan instruen-instrumen baru yang hanya dapat dikenali melalui disiplin ilmu lainnya seperti politik, sosial-budaya, arkeologi dan sains. Melalui pendekatan sains misalnya, pembaca masa kini dapat dipastikan memiliki pemahaman berbeda terhadap kisah tulah di Mesir.

Kontribusi penelitian ini adalah mengusulkan penggunaan RRC sebagai salah satu langkah hermenetika agar berjalan paralel dengan model eksegesis yang selama ini sangat kuat pengaruhnya di dalam teologi Kristen. Teknik ini juga dapat diperluas pemakaiannya di dalam hermenetika teksteks kitab suci lainnya khususnya di dalam memberikan alternatif dari mainstream hermenetika Injili. Koridor kehati- hatian tetap diperlukan karena teks kitab suci bukanlah karya sastra belaka dan berbeda dengan tulisan ber-genre politik, sosial atau budaya. Memegangnya sebagai tulisan yang suci, berotoritas dan berwibawa adalah syarat mutlak. Itu sebabnya, jauh lebih penting bagi RRC untuk mengantar pembaca masa kini memahami teks-teks tersebut untuk mendapatkan makna teologis daripada makna harafiahnya.

\section{Referensi}

Armiwulan, H. (2015). Diskriminasi Rasial Dan Etnis Sebagai Persoalan Hukum Dan Hak Asasi Manusia. MasalahMasalah Hukum, 44(4), 493. https://doi.org/10.14710/mmh.44.4.2015.493-502

Blumenthal, F. (2012). The Ten Plagues: Debunking Egyptian Polytheism. Jewish Bible Quarterly, 40(4), 255.

Budiman, A. (2013). Politik Apartheid Di Afrika Selatan. Jurnal Artefak, 1(1), 17. https://doi.org/10.25157/ja.v1i1.309

Fish, S. (1980). Interpreting the Varioum. In J. P. Thompkins (Ed.), Reader Respons Criticism (pp. 164-184). Baltimore: Johns Hopkins University Press.

Grimaud, M., \& Tompkins, J. P. (1982). Reader-Response Criticism: From Formalism to Post-Structuralism. The Journal of Aesthetics and Art Criticism, 41(1), 108. https://doi.org/10.2307/430832

Grossman, J. (2014). The structural paradigm of the ten Plagues narrative and the hardening of Pharaoh's heart. Vetus Testamentum, 64(4), 588-610. https://doi.org/10.1163/15685330-12341173

Hort, G. (1958). The Plagues of Egypt. Zeitschrift Fur Die Alttestamentliche Wissenschaft, 70(1), 48-59. https://doi.org/10.1515/zatw.1958.70.1.48

Klein, W. W., Blomberg, C. L., \& Hubbart, R. L. (2004). Introduction to Biblical Interpretation. Nashville, Tennessee: Thomas Nelson Inc.

Mantiri, L. G. (2019). Pentingnya Komunikasi dalam Penafsiran Alkitab. BIA': Jurnal Teologi Dan Pendidikan Kristen Kontekstual, 2(1), 108-120. https://doi.org/10.34307/b.v2i1.75

Nelson's Complete Book of Bible Maps and Charts. (1993). Nashville, Tennessee: Thomas Nelson, Inc.

Nobel, P. R. (1993). Synchronic and diachronic approaches to biblical interpretation. Literature and Theology, 7(2), 130-148. https://doi.org/10.1093/litthe/7.2.130

O'Hara, D. T., \& Iser, W. (1979). The Act of Reading: A Theory of Aesthetic Response. In The Journal of Aesthetics 
and Art Criticism (Vol. 38). https://doi.org/10.2307/430052

Osborne, G. R. (2006). The Hermeneutical Spiral (2nd ed.). Downer s Grove, Illionis: IVP Academic.

Osborne, G. R. (2012). Spiral Hermeneutika: Pengantar Komprehensif Bagi Penafsiran Alkitab. Surabaya: Momentum. Pawson, D. (2015). Unlocking the Bible (3rd ed.). London: William Collins.

Reader-Response Criticism. (2008). In Modern Literary Theory and Ancient Texts (pp. 86-97). https://doi.org/10.1002/9780470692295.ch6

Shanks, H., Dever, W. G., Halpern, B., \& Kyle McCarter, P. (2012). The Rise of Ancient Israel. In (Book).

Silva, Á. (2018). The Invention of Religion: Faith and Covenant in the Book of Exodus. Mayéutica, 44(97), $216-217$. https://doi.org/10.5840/mayeutica2018449710

Soulen, R. N., \& Soulen, R. K. (2001). Handbook of Biblical Criticism. Louisville, Kentucky: Westminster John Knox Press.

Sumaryono, E. (2018). Hermenetik (14th ed.). Yogyakarta: Kanisius.

Talshir, Z. (2018). Synchronic and Diachronic Approaches in the Study of the Hebrew Bible: Text Criticism within the Frame of Biblical Philology. Textus, 23(1), 1-32. https://doi.org/10.1163/2589255x-02301002

Walton, J. H., Matthews, V. H., \& Chavalas, M. C. (2000). The IVP Bible Background Commentary - Old Testament. Downer s Grove, Illionis: IVP Academic.

Wenham, G. J. (2003). Exploring the Old Testament (1st ed.). Downer s Grove, Illionis: InterVarsity Press.

Zaluchu, S. E. (2020a). Dinamika Hoax, Post-Truth dan Response Reader Criticism di Dalam Rekonstruksi Kehidupan Beragama. Religió: Jurnal Studi Agama-Agama, 10(1), 98-117. https://doi.org/10.15642/religio.v10i1.1310

Zaluchu, S. E. (2020b). Pentateuch - Narasi Narasi Utama Kitab Musa (1st ed.). Semarang: Golden Gate Publishing.

(C) 2020 by the authors. Submitted for possible open access publication under the terms and conditions of the Creative Commons Attribution (CC BY SA) license (https://creativecommons.org/licenses/by-sa/3.0/). 